\title{
Effectiveness of XP-Endo Finisher in the reduction of bacterial load in oval-shaped root canals
}

\section{Maria Cristina CARVALHO(a) \\ Mario Luis ZUOLO(a) (D) \\ Rodrigo ARRUDA-VASCONCELOS(a) \\ Ariane Cássia Salustiano \\ MARINHO(a) \\ Lidiane Mendes LOUZADA ${ }^{(a)}$ \\ Priscila Amanda FRANCISCO(a) \\ Vanessa Galego Arias PECORARI(a) \\ Brenda Paula Figueiredo de Almeida GOMES(a)}

(a) Universidade Estadual de Campinas - Unicamp, Piracicaba Dental School, Department of Restorative Dentistry, Piracicaba, São Paulo, Brazil.

Declaration of Interests: The authors certify that they have no commercial or associative interest that represents a conflict of interest in connection with the manuscript.

Corresponding Author:

Brenda Paula Figueiredo de Almeida Gomes

E-mail: bpgomes@fop.unicamp.br

https://doi.org/10.1590/1807-3107bor-2019.vol33.0021

Submitted: June 17, 2018

Accepted for publication: November 05, 2018

Last revision: February 26, 2019

\begin{abstract}
This study investigated the effectiveness of XP-Endo Finisher (XPF) associated with XP-Endo Shaper (XPS) or Reciproc Blue (RB) files in reducing bacterial load in oval-shaped root canals (RC) during chemomechanical preparation $(\mathrm{CMP})$ using $0.9 \%$ saline solution $(\mathrm{NaCl})$ or $2.5 \%$ sodium hypochlorite $(\mathrm{NaOCl})$. Eighty mandibular incisors with single oval-shaped RC were contaminated with Enterococcus faecalis. The teeth were randomly assigned to eight experimental groups $(n=10)$ according to the CMP, as follows: G1: XPS, G2: XPS + XPF, G3: RB, and G4: $\mathrm{RB}+\mathrm{XPF}$. CMP was performed with $\mathrm{NaCl}$ or $\mathrm{NaOCl}$. The reduction of bacterial load was assessed by colony-forming unit count before (S1) and after (S2) CMP. Data normality was verified by using Shapiro-Wilk test. ANOVA, Tukey's test, and Bonferroni post-hoc test were used at a $5 \%$ significance level. Culturable bacteria were present in all S1 samples $(p>0.05)$. All instrumentation techniques were effective in reducing bacterial load, irrespective of the irrigating solution $(p<0.05)$. With the use of $\mathrm{NaCl}, \mathrm{RB}$ was more effective than XPS ( $\mathrm{p}=0.035)$. With the use of $\mathrm{NaOCl}, \mathrm{XPS}$ and RB presented similar effectiveness ( $p=0.779)$. XPF enhanced the bacterial reduction of both systems tested $(p<0.05)$. The use of $\mathrm{NaOCl}$ improved the CMP, irrespective of the instrumentation technique used $(\mathrm{p}<0.05)$. In conclusion, XPS and RB files are effective in reducing bacterial levels in oval-shaped $\mathrm{RC}$. The use of XPF as a method of agitation of the irrigating solution improved the cleaning efficiency of both file systems tested. Mechanical preparation performed with saline solution decreased culturable bacteria from the root canal, but antimicrobial substances such as $\mathrm{NaOCl}$ should be used to achieve a significantly better disinfection.
\end{abstract}

Keywords: Enterococcus faecalis; Sodium Hypochlorite; Biofilms; Endodontics.

\section{Introduction}

The main goal of endodontic therapy is to prevent or eliminate apical periodontitis by means of cleaning, shaping, disinfecting, and filling the root canal system. The removal of microorganisms is considered the most important step in root canal therapy. ${ }^{1,2,3}$ Anaerobic bacteria, particularly gram-negative species, have been linked to the signs and symptoms of periapical disease. Facultative gram-positive bacteria, such as Enterococcus 
faecalis, have also been detected in infected root canals and may be related to failure of root canal treatment, showing capacity to survive intracanal procedures. ${ }^{1,4,5}$

Mechanical preparation of the root canals is recognized as one of the most important stages in root canal treatment. Although many advances in file designs have been made in the last decades, irrespective of the technique used, several studies have shown that complete removal of organic tissues/debris ${ }^{6,7,8}$ and bacteria ${ }^{9,10}$ is not commonly attained.

Several single-file techniques for root canal instrumentation have been introduced recently. Literature has shown no differences in the elimination of bacteria from root canals by comparing single-file to multi-file systems. ${ }^{11,12}$ Reciproc Blue (VDW, Munich, Germany) is a system which uses reciprocating motion $^{13}$ and has a newly developed alloy obtained through a thermomechanical manufacturing process, resulting in a specific oxide surface layer. ${ }^{13} \mathrm{XP}$-Endo Shaper (FKG Dentaire SA, La Chaux-de-Fonds, Switzerland) is also a single-file instrument, but it uses rotary motion, with the purpose of cleaning and shaping the root canals. ${ }^{14}$ It is manufactured from a MaxWire ${ }^{\circledR}$ alloy and has flexibility and fatigue strength, being able to expand and to be advanced easily and quickly into the canal at a reduced risk of torsional fatigue. ${ }^{14}$

It is known that most of the available systems fail to perform adequate cleaning and shaping, leaving untouched areas within the root canal. ${ }^{6,8}$ Moreover, considering all the challenges involved during endodontic treatment (i.e., isthmuses, intercanal communications, curvatures, and oval-shaped canals), a supplementary cleaning approach associating mechanical preparation with root canal irrigants (i.e., sodium hypochlorite) and new irrigation technologies may help in everyday clinical practice. ${ }^{15}$

XP-Endo Finisher (FKG Dentaire SA) has been recently introduced as an adjunctive approach to improve the effectiveness of irrigation and disinfection during chemomechanical preparation (CMP). Apparently, this instrument has the potential to be used as an additional therapeutic procedure in order to maximize bacterial removal. ${ }^{16}$ Changes in this newly developed file were proposed to increase its effectiveness in touching larger areas of the root canal walls and dislodging biofilms that remain after CMP. Thus, the present study aimed to investigate the effectiveness of XP-Endo Finisher associated with XP-Endo Shaper or Reciproc Blue files in reducing bacterial load in oval-shaped root canals during CMP using $0.9 \%$ saline solution $(\mathrm{NaCl})$ or $2.5 \%$ sodium hypochlorite $(\mathrm{NaOCl})$. The null hypothesis was that there are no differences in bacterial reduction with the additional use of XP-Endo Finisher.

\section{Methodology}

\section{Specimen selection and preparation}

This study was revised and approved by the Research Ethics Committee of the Piracicaba Dental School, State University of Campinas - UNICAMP (CAAE: 48274215.6.0000.5418). The specimens were selected according to Silva et al. ${ }^{17}$ Briefly, a sample of 80 mandibular incisors was selected from a pool of teeth extracted for reasons not related to this study and stored in $0.1 \%$ thymol solution at $5^{\circ} \mathrm{C}$. Digital radiographs were taken in the buccolingual and mesiodistal directions to select only teeth with single oval-shaped root canals, with a cross-section diameter ratio $\geq 2.5: 1$ at $5 \mathrm{~mm}$ from the apex. After acquiring digital images of each specimen, the angle of curvature was measured with the aid of image analysis software (AxioVision 4.5; Carl Zeiss Vision, Hallbergmoos, Germany). Teeth with root curvature $<10^{\circ}$ and initial apical size equivalent to a \#15 K-file (Dentsply Sirona, Ballaigues, Switzerland) were included in the present study. Pairs of teeth were selected on the basis of similar radiographic root canal morphology, and each tooth from each pair was randomly assigned to each experimental group. Exclusion criteria were as follows: presence of dental caries, fractures, immature apex, multi-rooted teeth, no calcifications, no internal or external root resorptions, no dental posts or prosthetic crowns, and no prior endodontic treatment.

Conventional access cavities were prepared by using round burs (KG Sorensen, Cotia, Brazil) and Endo-Z burs (Dentsply Maillefer, Ballaigues, Switzerland). A glide path was created by introducing a stainless steel of size \#15 K-file (Dentsply, Maillefer, Ballaigues, Switzerland) up 
to the working length (WL), which was established at the apical foramen.

All teeth were instrumented at the apical foramen up to a size of \#25 K-file in alternating rotation motions under continuous irrigation with $10 \mathrm{~mL}$ of distilled water. The smear layer was removed by using 17\% EDTA for 3 minutes followed by copious irrigation with $5 \mathrm{~mL}$ of distilled water. Irrigation was performed by using a NaviTip needle (Ultradent, South Jordan, UT, USA) placed as much apically as possible to ensure that the irrigants could reach the entire extent of the canal. The teeth were then immersed in brain heart infusion broth (BHI, Difco, Kansas City, MO, USA), ultrasonically activated for 1 minute to release entrapped air and allow penetration of the culture medium into root canal irregularities. Next, the teeth were sterilized in an autoclave for 20 minutes at $121^{\circ} \mathrm{C}$.

\section{Contamination with Enterococcus faecalis}

Enterococcus faecalis (ATCC 29212) was used to infect the root canals. The specimen contamination protocol was adapted from Andrade et al. ${ }^{18}$ Briefly, E. faecalis was reactivated in $\mathrm{BHI}$ broth and maintained at $37^{\circ} \mathrm{C}$ for 24 hours. The bacterial culture was transferred to another BHI flask and incubated for another 24 hours to achieve exponential growth. This culture was adjusted to McFarland standard \#1 $\left(3 \times 10^{8} \mathrm{CFU} / \mathrm{mL}\right)$ by means of a spectrophotometer (Bel Photonics do Brasil Ltda, Osasco, Brazil). First, $800 \mu \mathrm{L}$ of sterilized BHI was inserted in each Eppendorf tube (Axygen Scientific, Union City, USA) containing the specimen. Activation was performed in an ultrasonic bath for 15 minutes to allow for maximum penetration of the culture medium into the dentinal tubules prior to bacterial contamination. Contamination using the standardized inoculum was performed for 10 days, with centrifugation on alternate days to allow bacterial penetration into the root canal system. Following adjustment of the $E$. faecalis culture, it was incubated again at $37^{\circ} \mathrm{C}$ for 7 hours in order to achieve exponential growth. The inoculum $(800 \mu \mathrm{L})$ was inserted into Eppendorf tubes with the specimens and centrifuged (Eppendorf 5417R centrifuge, Eppendorf, Hamburg, Germany) in sequence at $1,400,2,000,3,600$, and 5,600 $\mathrm{g}$ in two five-minute cycles for each speed. The inoculum was renewed at each centrifugation cycle. Following the eight centrifugation cycles, sterilized BHI broth was inserted into Eppendorf tubes, agitated in a vortex mixer (Vortex-mix, Edison, USA), and incubated at $37^{\circ} \mathrm{C}$ for 24 hours (This protocol was repeated on days 1, 3, 5, 7, and 9). Following incubation (day $2)$, the samples were agitated again in a vortex mixer for 10 seconds, and the inoculum from the Eppendorf tubes was discarded. One milliliter of sterilized BHI broth was inserted, followed by a centrifugation cycle of $3,600 \mathrm{~g}$ for 5 minutes at $25^{\circ} \mathrm{C}$, and the Eppendorf tubes were incubated again at $37^{\circ} \mathrm{C}$ for 24 hours (This protocol was repeated on days 2, 4, 6, and 8). On day 10, the samples were removed from Eppendorf tubes, excess culture medium was removed, and the external root surfaces wiped with sterile gauze. Figure shows bacterial penetration into the dentinal tubules by scanning electron microscopy (SEM). A pilot study showed that 10 day was enough to contaminate the root canals using the contamination protocol.

The apical foramen of each experimental tooth was sealed with a fast-setting epoxy resin to prevent apical bacterial leakage and to create a closed-ended channel that produces the vapor lock effect. ${ }^{19}$ The teeth were mounted vertically up to the cervical region in blocks made of silicone impression material

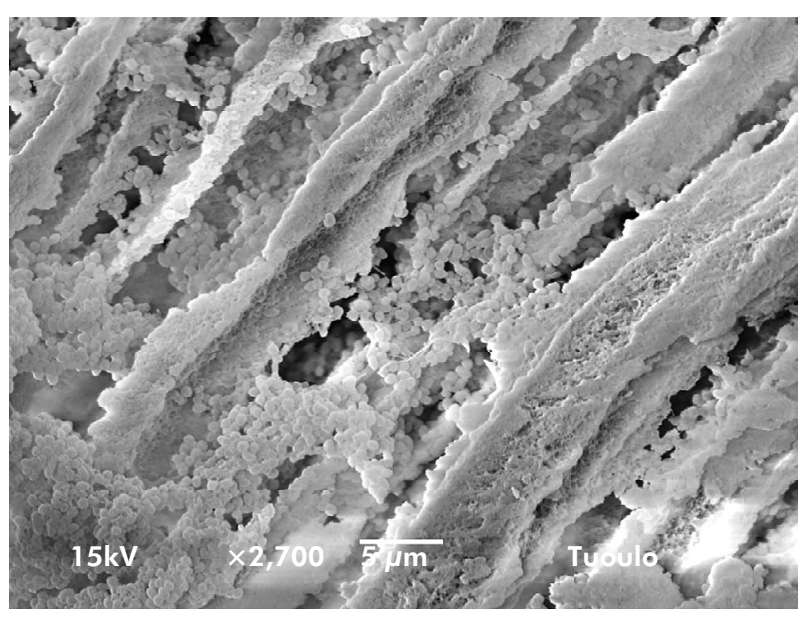

Figure. Scanning electron microscopic image of Enterococcus faecalis biofilm formation in the root canal walls and within the dentinal tubules. 
(President Jet; Coltene AG, Cuyahoga Falls, OH, USA). The tooth crown, including the pulp chamber walls, and the silicone surface were disinfected with $2.5 \% \mathrm{NaOCl}$, followed by inactivation with $10 \%$ sodium thiosulfate.

\section{Sampling and culture procedures}

Initial bacteriological samples (S1) were taken from all canals, irrigated with $1 \mathrm{~mL}$ of sterile saline solution, before CMP.

Bacteria were recovered by moving a sterile precurved stainless steel size \#25 Hedstroem file (Dentsply-Maillefer, Ballaigues, Switzerland) three times along the dentin wall from apical to coronal thirds and then placing the file into a sterile tube containing $1 \mathrm{~mL}$ of $\mathrm{BHI}$ broth for bacterial sampling. Next, a sterile paper point (Dentsply-Maillefer, Ballaigues, Switzerland) was introduced into the full working length of the canal and retained in position for 60 seconds. Other two paper points were consecutively introduced and then transferred to a sterile tube as described above.

The method for counting the colony-forming unit per milliliter $(\mathrm{CFU} / \mathrm{mL})$ has been previously published by Marinho et al. ${ }^{12}$ Briefly, the Eppendorf tubes containing the root canal samples were shaken thoroughly for 60 seconds (Vortex; Marconi, Piracicaba, Brazil) and then serial 10-fold dilutions were made up to $10^{-4}$ in tubes containing BHI broth. By using sterile plastic spreaders, $50 \mu \mathrm{L}$ of each serial dilution was plated onto $5 \%$ defibrinated sheep blood BHI agar plates and subjected to bacterial count after 48 hours of incubation at $37^{\circ} \mathrm{C}$. The tubes containing the serial dilutions were kept in the incubator at $37^{\circ} \mathrm{C}$ for 7 days to confirm microbial growth.

\section{Chemomechanical preparation protocol}

An experienced operator performed the CMP of all specimens. During the experiment, only one instrument was used for each tooth. The teeth were randomly assigned to eight groups $(n=10)$ by using a computer algorithm (http://www.ramdom.org) and according to the disinfection protocol.

All procedures were performed at $37^{\circ} \mathrm{C}$ inside a laminar flow cabinet containing a heater (800-Heater; PlasLabs, Lansing, USA). In all groups, the teeth were irrigated with $0.9 \% \mathrm{NaCl}$ or $2.5 \% \mathrm{NaOCl}$ at $37^{\circ} \mathrm{C}$ by using a syringe and a 30 -gauge NaviTip needle (Ultradent, South Jordan, USA). The irrigation needle was placed $2 \mathrm{~mm}$ short from the WL. The total volume of irrigating solution used in all specimens was standardized to $20 \mathrm{~mL}$ during $\mathrm{CMP}$, according to Marinho et al. ${ }^{12} \mathrm{Next}$, the specimens irrigated with $2.5 \% \mathrm{NaOCl}$ were inactivated by using $5 \mathrm{~mL}$ of $5 \%$ sodium thiosulfate, whereas in the $0.9 \% \mathrm{NaCl}$ groups, the specimens were irrigated with $5 \mathrm{~mL}$ of $0.9 \% \mathrm{NaCl}$ to standardize the total volume of solution used during the experiment. A final flush with $5 \mathrm{~mL}$ of $0.9 \% \mathrm{NaCl}$ was performed in both groups. The irrigating solution was evacuated during CMP by using 0.36-mm capillary tips (Ultradent Products INC, South Jordan, USA). The contact time between the irrigants and the root canal walls was 4 minutes (time for CMP). In the groups in which XP-Endo Finisher was used, an additional minute was necessary. In the groups without agitation, irrigating solutions were kept in contact for the same period (1 minute) to standardize the total amount of time (5 minutes).

XP-Endo Shaper Group: Twenty teeth were instrumented with XP-Endo Shaper according to the manufacturer's recommendations. XP-Endo Shaper was used until reaching the WL by applying up-and-down movements. These movements were repeated three times until the WL was reached. After reaching the $\mathrm{WL}$, the XP-Endo Shaper instrument was cleaned and the canal was irrigated with $0.9 \% \mathrm{NaCl}$ $(\mathrm{n}=10)$ or $2.5 \% \mathrm{NaOCl}(\mathrm{n}=10)$ and another 10 gentle movements were performed at the $\mathrm{WL}$.

$X P$-Endo Shaper + XP-Endo Finisher Group: Twenty teeth were instrumented with XP-Endo Shaper as described before and an additional approach with XP-Endo Finisher was performed according to the manufacturer's recommendations. XP-Endo Finisher was used in the canal for 1 minute at $800 \mathrm{rpm}$ and $1 \mathrm{Ncm}$ up to the WL and in slow up-and-down movements at 8-mm length.

Reciproc Blue Group: Twenty teeth were instrumented with Reciproc Blue R25 file. The instrument was gently inserted into the cervical third with an in-and-out pecking motion, with a light apical pressure in a reciprocating motion ('RECIPROC ALL') powered by an electric motor (VDW Silver GmbH, Munich, 
Germany) with low amplitude until the WL was reached. After three in-and-out movements, the instrument was removed from the canal and cleaned.

Reciproc Blue + XP-Endo Finisher Group: Twenty teeth were instrumented with Reciproc Blue R25 file as mentioned above and an additional approach with XP-Endo Finisher was performed as described before.

After CMP, a post-instrumentation sample (S2) from all specimens was performed as described above.

\section{Statistical analysis}

An initial screening for data normality was performed by using the Shapiro-Wilk test. Comparison between the experimental groups was carried out by ANOVA and post-hoc Tukey's tests. For comparison between the samples within each group, the repeated-measures ANOVA and Bonferroni post-hoc tests were used. Alpha-type error was set at the $5 \%$ significance level $(\alpha=0.05)$. The resulting data were statistically analyzed by using SPSS for Windows (Chicago, IL, USA).

\section{Results}

Table provides an overview of the amount of culturable bacteria $(\mathrm{CFU} / \mathrm{mL})$ between the groups before (S1) and after (S2) CMP. Culturable bacteria were present in all S1 samples (80/80) ( $p>0.05)$.

All instrumentation techniques were effective in reducing bacterial load, irrespective of the irrigating solution used $(p<0.05)$.
After $\mathrm{CMP}$ using $0.9 \% \mathrm{NaCl}$ as irrigating solution, Reciproc Blue was more effective than XP-Endo Shaper $(p=0.035)$. However, the association with $X P$-Endo Finisher improved the cleaning efficacy of both file systems ( $p=0.239)$. After CMP (S2) using $2.5 \% \mathrm{NaOCl}$ as irrigating solution, $\mathrm{XP}$-Endo Shaper and Reciproc Blue presented similar effectiveness in root canal disinfection ( $p=0.779)$. Nevertheless, $X P$-Endo Finisher enhanced bacterial reduction in both systems $(p<0.05)$.

The use of $2.5 \% \mathrm{NaOCl}$ improved CMP, irrespective of the instrumentation technique used $(p<0.05)$.

\section{Discussion}

Cross-sectional root canal configurations have been classified as round, oval, long oval, flattened, or irregular canals. Oval canals have a buccolingual diameter twice greater than the mesiodistal diameter, whereas long oval canals have a buccolingual diameter twice to four times greater than the mesiodistal diameter. ${ }^{20,21,22}$ Long oval canals occur in the apical portion in about $25 \%$ of cases and in some groups of teeth such as mandibular incisors and maxillary second premolars; however, their prevalence is greater than $50 \%{ }^{23}$ In the distal roots of mandibular molars, the prevalence is 25 to $30 \%{ }^{21}$

Oval-shaped canals were used in this study because they represent a challenge to clinicians. ${ }^{6,8,24,25,26}$ This root canal configuration possesses areas difficult to be shaped, cleaned, and filled, which increases

Table. Mean ( \pm SD) of CFU/mL before and after chemomechanical preparation using $0.9 \% \mathrm{NaCl}$ and $2.5 \% \mathrm{NaOCl}$ in the different groups.

\begin{tabular}{lcccc}
\hline \multirow{2}{*}{\begin{tabular}{l} 
Variable \\
\cline { 2 - 5 }
\end{tabular}} & \multicolumn{2}{c}{$0.9 \% \mathrm{NaCl}$} & \multicolumn{2}{c}{$2.5 \% \mathrm{NaOCl}$} \\
\hline XP-Endo Shaper & $215800( \pm 84,256)^{\mathrm{Aa}}$ & $681.2( \pm 118,700)^{\mathrm{Ab} 1}$ & $203600( \pm 77,882)^{\mathrm{Aa}}$ & $21.3( \pm 15,780)^{\mathrm{Ab} 2}$ \\
XP-Endo Shaper + XP-Endo Finisher & $150500( \pm 29,737)^{\mathrm{Aa}}$ & $181( \pm 46,540)^{\mathrm{Cb} 1}$ & $175200( \pm 42,949)^{\mathrm{Aa}}$ & $2.6( \pm 1,075)^{\mathrm{Bb} 2}$ \\
Reciproc Blue & $213300( \pm 80,465)^{\mathrm{Aa}}$ & $579.5( \pm 55,110)^{\mathrm{Bb} 1}$ & $190000( \pm 8,069)^{\mathrm{Aa}}$ & $16.6( \pm 15,420)^{\mathrm{Ab} 2}$ \\
Reciproc Blue + XP-Endo Finisher & $211700( \pm 55,140)^{\mathrm{Aa}}$ & $249.5( \pm 78,830)^{\mathrm{Cb} 1}$ & $193500( \pm 4,378)^{\mathrm{Aa}}$ & $2.5( \pm 1,958)^{\mathrm{Bb} 2}$ \\
\hline
\end{tabular}

$\mathrm{P}<0.05$ Means followed by different letters indicate statistically significant differences. Vertical uppercase letters show the comparison of the different groups using the same irrigating solution at the same time. Horizontal lowercase letters show the comparison within the same group before and after CMP. Different numbers represent statistically significant differences of irrigants used in the same technique and after CMP. 
bacterial load and, consequently, the potential failure of root canal therapy.

To the best of our knowledge, this is the first study to investigate the effectiveness of XP-Endo Finisher associated with XP-Endo Shaper or Reciproc Blue files in reducing bacterial load in oval-shaped root canals during $\mathrm{CMP}$ with $0.9 \%$ saline solution $(\mathrm{NaCl})$ or $2.5 \%$ sodium hypochlorite $(\mathrm{NaOCl})$. The inert irrigating solution $(\mathrm{NaCl})$ was used to test whether XP-Endo Shaper, Reciproc Blue, and XP-Endo Finisher were able to provide a satisfactory mechanical preparation, whereas $\mathrm{NaOCl}$ was chosen for being the most widely used root canal irrigant in endodontic practice.

Previous works in the literature have used $e x$ vivo models ${ }^{12,16}$ and E. faecalis contamination to evaluate the effectiveness of different protocols for root canal cleaning. ${ }^{12}$ In the present study, culture procedures revealed the presence of culturable bacteria in $100 \%$ of the initial samples (S1), thus validating the contamination protocol. Despite the limitations of sampling biofilm with a combination of sterile endodontic files/paper points, this is a well-established protocol. ${ }^{5,27,28}$

All instruments used in this study were effective in reducing bacterial load in oval-shaped root canals, irrespective of the irrigating solution used. This means that the instruments have proper mechanical characteristics. When $0.9 \% \mathrm{NaCl}$ was used as root canal irrigant, Reciproc Blue was more efficient than XP-Endo Shaper, probably because of its design, which favors a more robust touch of the root canal walls, dislodging biofilms from dentin and allowing their removal during irrigation. The use of a supplementary approach (XP-Endo Finisher) increased the cleaning efficacy of XP-Endo Shaper and Reciproc Blue systems. achieving the greatest reduction in the $2.5 \% \mathrm{NaOCl}$ group. This emphasizes the need of using antimicrobial substances during CMP for microbial control.

CMP performed with $2.5 \% \mathrm{NaOCl}$ provided a significantly greater reduction of bacterial load compared to $0.9 \% \mathrm{NaCl}$, irrespective of the instrument used, which is corroborated by Rodrigues et al. ${ }^{29}$ This result was not unexpected as $\mathrm{NaOCl}$ possesses antimicrobial activity and ability to dissolve organic tissues. ${ }^{30}$
In the current study, XP-Endo Finisher was successfully used to lower the levels of $E$. faecalis counts by agitation of the irrigating solutions. XP-Endo Finisher (25/.00) is manufactured from a MaxWire ${ }^{\circledR}$ alloy, and according to the manufacturer, it is straight in its martensite phase when cooled, changing to the austenite phase when exposed to body temperature $\left(37^{\circ} \mathrm{C}\right)$. XP-Endo Finisher has a unique spoon-shaped design with a $10-\mathrm{mm}$ length from the tip and a 1.5-mm depth. ${ }^{14,31}$ The manufacturer suggests this system should be used at $800 \mathrm{rpm}$ with irrigating solutions after root canal preparation to size \#25, allowing the instrument to reach difficult areas and even curved canals. XP-Endo Finisher has also the ability to remove intracanal medication ${ }^{32,33,34}$ and biofilm ${ }^{16}$ as well as to avoid apical extrusion of sodium hypochlorite, ${ }^{35}$ including its effectiveness in curved root canals. ${ }^{36}$ However, to date, only a few studies have evaluated the reduction of bacterial load by these instruments. ${ }^{16,35}$

The association of XP-Endo Finisher with XP-Endo Shaper or Reciproc Blue increased the effectiveness of $\mathrm{CMP}$ with the use of $\mathrm{NaCl}$ or $\mathrm{NaOCl}$. Therefore, the null hypothesis was rejected. This finding is in line with Bao et al., ${ }^{16}$ who observed that XP-Endo Finisher associated with passive ultrasonic activation and conventional irrigation improved biofilm removal in infected root canals. This is also corroborated by Azim et al., ${ }^{35}$ who reported that XP-Endo Finisher presented higher bacterial reduction within the main root canal and better results than conventional irrigation.

Our results show that although bacterial load decreased, no instrumentation technique or tested irrigant was able to completely eliminate bacteria in oval-shaped root canals. Therefore, the development of new instrumentation/irrigation systems, including instrument design, biofilm-targeting irrigants, and substances capable of promoting better disinfection and enhancing host response, is necessary to increase the predictability of endodontic therapy.

\section{Conclusion}

In conclusion, our findings show that single-file instrumentation carried out with XP-Endo Shaper and Reciproc Blue files is effective in reducing 
bacterial levels in oval-shaped root canals. The use of XP-Endo Finisher as a supplementary approach to the irrigation/instrumentation technique improved the cleaning efficiency of both file systems tested. Mechanical preparation performed with saline solution decreased culturable bacteria in the root canal, but antimicrobial substances such as $\mathrm{NaOCl}$ should be used to achieve a significantly better disinfection.

\section{Acknowledgments}

This study was supported by the Research Support Foundation of the State of São Paulo (FAPESP 2015/23479-5), National Scientific and Technological Development Council (CNPq - 308162/2014-5), and Coordination for Improvement of Higher Education Personnel (CAPES). We would like to thank Mr Maicon R Z Passini for technical support.

\section{References}

1. Gomes BP, Lilley JD, Drucker DB. Variations in the susceptibilities of components of the endodontic microflora to biomechanical procedures. Int Endod J. 1996 Jul;29(4):235-41. https://doi.org/10.1111/j.1365-2591.1996.tb01375.x

2. Hülsmann M, Rümmelin C, Schäfers F. Root canal cleanliness after preparation with different endodontic handpieces and hand instruments: a comparative SEM investigation. J Endod. 1997 May;23(5):301-6. https://doi.org/10.1016/S0099-2399(97)80410-4

3. Siqueira JF Jr, Araujo MC, Garcia PF, Fraga RC, Dantas CJ. Histological evaluation of the effectiveness of five instrumentation techniques for cleaning the apical third of root canals. J Endod. 1997 Aug;23(8):499-502. https://10.1016/S0099-2399(97)80309-3

4. Gomes BP, Drucker DB, Lilley JD. Associations of specific bacteria with some endodontic signs and symptoms. Int Endod J. 1994 Nov;27(6):291-8.

5. Gomes BP, Berber VB, Kokaras AS, Chen T, Paster BJ. Microbiomes of endodontic-periodontal lesions before and after chemomechanical preparation. J Endod. 2015 Dec;41(12):1975-84. https://doi.org/10.1016/i.joen.2015.08.022

6. De-Deus G, Barino B, Zamolyi RQ, Souza E, Fonseca A Jr, Fidel S et al. Suboptimal debridement quality produced by the single-file F2 ProTaper technique in oval-shaped canals. J Endod. 2010 Nov;36(11):1897-900. https://doi.org/10.1016/i.joen.2010.08.009

7. Taha NA, Ozawa T, Messer HH. Comparison of three techniques for preparing oval-shaped root canals. J Endod. 2010 Mar;36(3):532-5. https://doi.org/10.1016/i.joen.2009.11.015

8. Versiani MA, Pécora JD, de Sousa-Neto MD. Flat-oval root canal preparation with self-adjusting file instrument: a micro-computed tomography study. J Endod. 2011 Jul;37(7):1002-7. https://doi.org/10.1016/i.joen.2011.03.017

9. Barbosa-Ribeiro M, De-Jesus-Soares A, Zaia AA, Ferraz CC, Almeida JF, Gomes BP. Quantification of lipoteichoic acid contents and cultivable bacteria at the different phases of the endodontic retreatment. J Endod. 2016 Apr;42(4):552-6. https://doi.org/10.1016/j.joen.2016.01.002

10. Neves MAS, Provenzano JC, Roças IN, Siqueira JF Jr. Clinical antibacterial effectiveness of root canal preparation with reciprocating single-instrument or continuously rotating multi-instrument systems. J Endod. 2016 Jan;42(1):25-9. https://doi.org/10.1016/i.joen.2015.09.019

11. Alves FRF, Rôças IN, Almeida BM, Neves MA, Zoffoli J, Siqueira JF Jr. Quantitative molecular and culture analyses of bacterial elimination in oval-shaped root canals by a single-file instrumentation technique. Int Endod J. 2012 Sep;45(9):871-7. https://doi.org/10.1111/j.1365-2591.2012.02045.x

12. Marinho AC, Martinho FC, Gonçalves LM, Rabang HR, Gomes BP. Does the Reciproc file remove root canal bacteria and endotoxins as effectively as multifile rotary systems? Int Endod J. 2015 Jun;48(6):542-8. https://doi.org/10.1111/iej.12346

13. De-Deus G, Silva EJNL, Vieira VTL, Belladonna FG, Elias CN, Plotino G et al. Blue thermomechanical treatment optimizes fatigue resistance and flexibility of the reciproc files. J Endod. 2017 Mar;43(3):462-6. https://doi.org/10.1016/i.joen.2016.10.039

14. FKG Dentaire SA. The XP-endo Finisher file brochure. La Chaux-de-Fonds: FKG; 2016 [cited year Month day]. Available from: http://www.fkg.ch/products/endodontics/final-preparation/xp-endo-finisher

15. Plotino G, Cortese T, Grande NM, Leonardi DP, Di Giorgio G, Testarelli L et al. New technologies to improve root canal disinfection. Braz Dent J. 2016 Jan-Feb;27(1):3-8. https://doi.org/10.1590/0103-6440201600726

16. Bao P, Shen Y, Lin J, Haapasalo M. In vitro efficacy of XP-endo Finisher with 2 different protocols on biofilm removal from apical root canals. J Endod. 2017 Feb;43(2):321-5. https://doi.org/10.1016/i.joen.2016.09.021

17. Silva EJNL, Belladonna FG, Zuolo AS, Rodrigues E, Ehrhardt IC, Souza EM et al. Effectiveness of XP-endo Finisher and XP-endo Finisher R in removing root filling remnants: a micro-CT study. Int Endod J. 2018 Jan;51(1):86-91. https://doi.org/10.1111/iej.12788 
18. Andrade FB, Arias MP, Maliza AG, Duarte MA, Graeff MS, Amoroso-Silva PA et al. A new improved protocol for in vitro intratubular dentinal bacterial contamination for antimicrobial endodontic tests: standardization and validation by confocal laser scanning microscopy. J Appl Oral Sci. 2015 Nov-Dec;23(6):591-8. https://doi.org/10.1590/1678-775720140261

19. Tay FR, Gu LS, Schoeffel GJ, Wimmer C, Susin L, Zhang K et al. Effect of vapor lock on root canal debridement by using a side-vented needle for positive-pressure irrigant delivery. J Endod. 2010 Apr;36(4):745-50. https://doi.org/10.1016/i.joen.2009.11.022

20. Jou YT, Karabucak B, Levin J, Liu D. Endodontic working width: current concepts and techniques. Dent Clin North Am 2004 Jan;48(1):323-35. https://doi.org/10.1016/i.cden.2003.12.006

21. Mohammadi Z, Shalavi S, Jafarzadeh H. The oval shaped, root canal: a clinical review. S Afr Dent J 2015 Jun;70(5):200-4.

22. Shah DY, Wadekar SI, Dadpe AM, Jadhav GR, Choudhary LJ, Kalra DD. Canal transportation and centering ability of protaper and self-adjusting file system in long oval canals: an ex-vivo cone-beam computed tomography analysis. J Conser Dent 2017 Mar-Apr;20(2):105-9. https://doi.org/10.4103/0972-0707.212234

23. Wu MK, R'oris A, Barkis D, Wesselink PR. Prevalence and extent of long oval canals in the apical third. Oral Surg Oral Med Oral Pathol Oral Radiol Endod 2000 Jun;89(6):739-43. https://doi.org/10.1067/moe.2000.106344

24. Peters OA. Current challenges and concepts in the preparation of root canal systems: a review. J Endod. 2004 Aug;30(8):559-67. https://doi.org/10.1097/01.DON.0000129039.59003.9D

25. Versiani MA, Leoni GB, Steier L, De-Deus G, Tassani S, Pécora JD et al. Micro-computed tomography study of oval-shaped canals prepared with the self-adjusting file, Reciproc, WaveOne, and ProTaper universal systems. J Endod. 2013 Aug;39(8):1060-6. https://doi.org/10.1016/i.joen.2013.04.009

26. Zuolo ML, De-Deus G, Belladonna FG, Silva EJ, Lopes RT, Souza EM et al. Micro-computed tomography assessment of dentinal micro-cracks after root canal preparation with TRUShape and Self-adjusting File Systems. J Endod. 2017 Apr;43(4):619-622. https://doi.org/10.1016/i.joen.2016.11.013

27. Krokidis A, Bonfanti C, Cerittu A, Barabanti N, Zinelis S, Panopoulos P. Comparative analysis of SAF, Protaper Next and BTRace in eliminating Enterococcus faecalis from long oval canals: An ex vivo study. Aust Endod J. 2017 Dec;43(3):110-4. https://doi.org/10.1111/aej.12177

28. Hoedke D, Enseleit C, Gruner D, Dommisch H, Schlafer S, Dige I et al. Effect of photodynamic therapy in combination with various irrigation protocols on an endodontic multispecies biofilm ex vivo. Int Endod J. 2018 Jan;51 Suppl 1:e23-e34. https://doi.org/10.1111/iej.12763

29. Rodrigues RCV, Zandi H, Kristoffersen AK, Enersen M, Mdala I, Ørstavik D et al. Influence of the apical preparation size and the irrigant type on bacterial reduction in root canal-treated teeth with apical periodontitis. J Endod. 2017 Jul;43(7):1058-63 https://doi.org/10.1016/i.joen.2017.02.004

30. Zehnder M. Root canal irrigants. J Endod. 2006 May;32(5):389-98. https://doi.org/10.1016/i.joen.2005.09.014

31. Trope M, Debelian G. XP-3D Finisher file-the next step in restorative endodontics. Endod Pract US. 2015;8:22-4.

32. Keskin C, Sariyilmaz E, Sariyilmaz $€ O$. Efficacy of XP-Endo Finisher file in removing calcium hydroxide from simulated internal resorption cavity. J Endod. 2017 Jan;43(1):126-30. https://doi.org/10.1016/i.joen.2016.09.009

33. Gokturk H, Ozkocak I, Buyukgebiz F, Demir O. Effectiveness of various irrigation protocols for the removal of calcium hydroxide from artificial standardized grooves. J Appl Oral Sci. 2017 May-Jun;25(3):290-8. https://doi.org/10.1590/1678-7757-2016-0414

34. Turkaydin D, Demir E, Basturk FB, Sazak Övecoglu H. Efficacy of XP-Endo Finisher in the removal of triple antibiotic paste from immature root canals. J Endod. 2017 Sep;43(9):1528-31. https://doi.org/10.1016/i.joen.2017.04.017

35. Azim AA, Piasecki L, da Silva Neto UX, Cruz ATG, Azim KA. XP Shaper, a novel adaptive core rotary instrument: micro-computed tomographic analysis of its shaping abilities. J Endod. 2017 Sep;43(9):1532-8. https://doi.org/10.1016/i.joen.2017.04.022

36. Elnaghy AM, Mandorah A, Elsaka SE. Effectiveness of XP-endo Finisher, EndoActivator, and file agitation on debris and smear layer removal in curved root canals: a comparative study. Odontology. 2017 Apr;105(2):178-83. https://doi.org/10.1007/s10266-016-0251-8 